\title{
The influence of accountability, transparency, and affective and cognitive trusts on interest in paying zakat
}

\author{
Mohammad Fahmi Ikhwandha, Ataina Hudayati* \\ Faculty of Economics, Universitas Islam Indonesia, Yogyakarta, Indonesia \\ *Corresponding Author e-mail: ataina.hudayati@uii.ac.id
}

\section{A R T I C L E I N F O}

Article history:

Available online

Keywords:

transparency, accountability,

cognitive and affective trusts, interest in paying zakat

DOI:

https://doi.org/10.20885/jaai.vol23. $\underline{\text { iss 1.art5 }}$
A B S T R A C T

This research aimed to expand the previous study by investigating the role of two dimensions of trust concepts, namely affective trust and cognitive trust. Particularly, this research was to analyze the influence of accountability and transparency on affective and cognitive trusts. Moreover, the purpose of this research was to test the influence of cognitive and affective trust on the interest in paying zakat through zakat institution. The subject of this research was 100 muzakkis of BAZNAS (Badan Amil Zakat Nasional/National Board of Zakat) located in Provincial Region of Yogyakarta and in Yogyakarta City. The data analysis method used in this research was Partial Least Square. The result of this study has revealed that accountability positively affects affective and cognitive trusts. The study has also proven that affective and cognitive trusts positively affect the interest in paying zakat through zakat institution. On the other hand, this research has found that transparency has no effect on cognitive and affective trusts.

\section{Introduction}

The main problem faced by developing countries is economic problem which often results in negative impacts to people such as poverty and unemployment which may eventually stimulate crimes. To solve the problems, there must be an effort to overcome the poverty first. Islam has a teaching to solve poverty through the obligation of paying zakat since zakat may reduce the economic inequality in society (Shariff et al., 2011; Ali, 2014).

To increase the effectivity of zakat management, government issued Law No 23 of 2011 on Zakat Management. According to the Law, the purpose of zakat management includes a) to improve the service and to increase the efficiency of zakat payment; and b) to increase the benefit of zakat that will manifest the community welfare and eradicate poverty. As the response to the Law, the government and society established a zakat institution, renowned as National Board of Zakat (BAZNAS). BAZNAS is an official zakat institution and was established by the government based on Presidential Decree of Republic of Indonesia No.8 of 2001. According to the book entitled "Statistik Zakat Nasional 2017 (National Zakat Statistics 2017)" published by BAZNAS, the number of zakat management organizations in Indonesia was 603 comprising 548 branches of BAZNAS and 55 Lembaga Amil Zakat (Zakat Amil Institutions). Even though Indonesia has a plentiful number of zakat institutions, the realization of zakat acceptance in Indonesia is very low. In 2017, the percentage of zakat acceptance at national level was only $2.9 \%$ of the potential 217 trillion rupiahs (BAZNAS, 2018). Moreover, the number of people paying zakat through the zakat institutions is considered to be very low compared with the number of people who are obliged to pay zakat. In the period of 2006-2015, the number of people who paid zakat - through zakat institutions in Indonesia was less than $0.1 \%$ (Canggih et al., 2017). Hence, it can be said that there are only a few numbers of people who are willing to pay zakat through zakat institution, so greater efforts from various parties to make people entrust their zakat management to zakat institution are certainly needed.

To increase the management quality of zakat institution as well as the interest of people in paying zakat through zakat institution, the academics, through their studies, have discussed some factors that may affect the interest in paying zakat. One of them is muzakki's trust in zakat institution. The study conducted by Rouf (2011), Sidiq (2015), Azimah (2016), Yunus (2016), and Triyawan and Aisyah (2016) found that people's trust in zakat institutions positively and significantly affected the muzakki's interest in paying zakat through zakat institutions.

According to McAllister (1995) as well as Johnson and Grayson (2005), the concept of trust can be divided into affective and cognitive trusts. Different from the previous research which discussed the influence of trust towards the interest in paying zakat (Rouf, 2011; Sidiq, 2015; Azimah, 2016; Yunus, 2016; Triyawan \& Aisyah, 
2016), this research discusses the influence of the two dimensions of trust concept, namely affective trust and cognitive trust, on the interest in paying zakat.

In addition to discussing the influence of trust on muzakki's interest in paying zakat through zakat institutions, the foregoing research also studied the influence of transparency and accountability on the trust (Nasim \& Romdhon, 2014; Nurrizkiana et al., 2017). Those study implied that accountability and transparency positively affected muzakki's trust in paying zakat through zakat institutions. Since this research used two dimensions of trust, this paper will discuss the influence of transparency and accountability on affective and cognitive trusts.

The purpose of this research was to analyze: a) the influence of transparency on affective trust; $b$ ) the influence of transparency on cognitive trust; c) the influence of accountability on affective trust; d) the influence of accountability on cognitive trust; e) the influence of affective trust on the interest in paying zakat; and f) the influence of cognitive trust on the interest in paying zakat. The next parts of this paper will discuss the theoretical framework and hypothesis formulation, research method, data analysis, conclusion, suggestions, and implications.

\section{Literature Review}

\section{Attribution Theory and Agency Theory}

Attribution theory declares that when an individual is observing someone's behavior, it means that the individual is trying to find whether the behavior is caused by internal or external factor (Robbins \& Judge, 2008). A behavior that appears because of internal factor is believed to be under the control of the individual oneself, while a behavior caused by external factor is stimulated from outside, meaning that the individual will be forced to behave according to the demand of a situation or an environment.

Attribution theory is deemed relevant in a discussion on the influence of external and internal factors on our and/or others' behaviors. Hence, attribution means an effort to understand the cause behind our own and/or others' behaviors. Transparency and accountability are the external factors that may affect the muzakki' s behavior because the factors result from BAZNAS performance in managing zakat, while affective and cognitive trusts are internal factors resulting from the muzakkis themselves.

The second theory that becomes the basis of this research is Agency theory which was developed by Ross (1973), Jensen and Meckling (1976), and Eisenhardt (1989). Ross (1973) stated that the agency relation between two parties or more would be formed if one of them (the agents) acts as the other party's representative (principal) to do a certain decision-making process for a certain problem. The agency relation is broad which includes the relations between owner and manager, employer and worker, seller and buyer, and relations with other agencies (Ross, 1973; Eisenhardt, 1989). Agency theory considers that company is a central of contract between agent and principal (Jensen \& Meckling, 1976). Agency theory assumes that there are two problems faced by an organization, conflict of interest that arises between agent and principal when the agent tends to avoid the work and the problems related to risk sharing when agent tends to avoid risk (Jensen \& Meckling, 1976; Eisenhardt, 1989). Those two problems that emerge due to agent's selfishness (self-interest) will harm principal's interest and eventually inhibit them to achieve the organization's objectives. Due to agent's selfish characteristic, an accounting and reporting systems with the role as a tool to monitor agent's behavior were formed. The accounting and reporting systems will reduce the information asymmetry between agent and principal. If principal and agent have the same information regarding the organization operation, it is expected that the agent will tend to behave according to the organization's interest. In this research, the agent was represented by the manager or administrator of BAZNAS, while the principal was muzakki (zakat payer).

\section{Affective Trust and Cognitive Trust}

Trust can be defined as the belief of one party in the other party because the other party is competent, open, caring, and reliable (Zur et al., 2012). Another research defines trust as an expectation or positive hope that other person would not act opportunistically (Robbins \& Judge, 2008). Trust is an important factor in exchange transaction between business partners.

Trust can be based on rational aspect (cognitive) and emotional aspect (affective). Some literatures state that both types of trusts must be distinguished because both of them may differently affect an organization effectiveness (McAllister, 1995; Johnson \& Grayson, 2005). Having a reputation as a satisfying partner will lead an agent to gain cognitive trust, which in turn will affect principal's willingness to cooperate with the agent. Affective trust will emerge if both partnered parties have an emotional bond that will enable each party to feel safe during a transaction/cooperation.

Affective trust is a trust based on the feeling resulting from partner's attention. This affective trust is indicated by the consumer's feeling of being protected during a transaction with a company (Johnson \& Grayson, 
2005). Cognitive trust is a trust or a willingness of a customer to rely on the competence and reliability of a service provider (Johnson \& Grayson, 2005).

\section{Hypothesis Development}

\section{The influence of transparency on affective trust}

Transparency is a condition in which a company can provide the materials and relevant information related to the company which can be easily accessed and understood by the stakeholders (KNKG, 2006). Transparency is so important that it may ensure the effectiveness of an organization management. A transparent environment will increase the society trust in the organization (Kiow et al., 2017). Company must take an initiative to expose not only the problems required by law, but also the important matters for decision making of various parties. Due to the importance of transparency, National Committee of Governance Policy (Komite Nasional Kebijakan Governance/KNKG) states that transparency is one of the principles of Good Corporate Governance (KNKG, 2006). If zakat institution gives complete information that is easily accessible and understood by all of the stakeholders including muzakki, the muzakki's trust in the zakat institution will increase.

Attribution theory is relevant to explain the relations between transparency and affective trusts because muzakki's knowledge on the financial report of zakat institution is an external cause that affects the muzakki's affective trust in zakat institution. Furthermore, Agency theory predicts that information transparency will reduce information asymmetry between muzakki and zakat institution which encourages zakat institution to behave in accordance with the muzakki's interest. The compliance of zakat institution behavior with the muzakki's interest will increase muzakki's affective trust in zakat institution.

The research of Nasim and Romdhon (2014) found that transparency of financial report had positive and significant effect on muzakki's trust in zakat institution. Financial report transparency means the willingness to give information to the public as a form of responsibility conducted by zakat institution. If zakat institutions are willing to show responsible attitude, muzakki's trust will increase. In addition, the research in public sector conducted by Nurrizkiana et al. (2017) also revealed that transparency positively and significantly affected people's trust in government. Kiow et al. (2017) in his conceptual study regarding tax compliance also described that transparency had positive impact on people's ethical perception toward government which would result in the increase in tax compliance.

Up to the writing of this research, the researcher has not yet found another research that relates transparency and affective trust. Nasim and Romdhon (2014) claimed that trust had three dimensions, those were credibility, competence, and moral attitude. The moral attitude aspect will likely to be in form of trust involving emotional factor, for which it was mentioned as affective trust in this research. Hence, it can be assumed that transparency affects affective trust in zakat institution. Based on the above description, the first hypothesis is formulated as follows.

H1: Transparency positively affects affective trust.

\section{The influence of transparency on cognitive trust}

Trust emerges from the accumulation of knowledge that enables someone to make a prediction regarding the possibility that a partner will fulfill its obligation. Beside explaining the relation between transparency and affective trust, Attribution theory and Agency theory also explain the relations between transparency and muzakki's cognitive trust in zakat institution. With the help of transparency, muzakki's perception in zakat institution competence can be developed, and it will increase muzakki's cognitive trust eventually.

As far as the researcher concerns, there have been no previous studies investigating the influence of transparency on cognitive trust. However, the research conducted by Nasim and Romdhon (2014), as well as Nurrizkiana et al. (2017) showed that transparency positively affected trust. Since trust has rational and emotional dimensions, the foregoing study which found the fact that transparency could increase trust was used in this research to predict that transparency could also increase cognitive trust. Based on the above description, the second hypothesis is formulated as follows.

H2: Transparency positively affects cognitive trust.

\section{The influence of accountability on affective trust}

Accountability is a form of company responsibility to the stakeholders (Rahman, 1998). Accountability is an effort or activity to produce appropriate disclosure. Accountability is also attached to social role for which muhtasib 
(accountant) believes that sharia law has been performed and that public welfare finally becomes the main objective of the company activities (Abu-Tapanjeh, 2009).

Attribution theory is relevant to explain the role of accountability to improve the trust of muzakki in zakat institution because muzakki's knowledge on the quality of zakat institution is considered to be the external cause that affects muzakki's affective trust in paying zakat. Meanwhile, the relevance of Agency theory to explain the relation between accountability and affective trusts is that, with the existence of good accountability, muzakki will be able to gain the sense of being noticed and appreciated so that muzakki's affective trust will be increased. Hence, muzakki will feel safe to pay zakat to zakat institution because they believe that the zakat will be distributed to those who deserve it.

It seems that the foregoing studies did not have a discussion on accountability influence on affective trust. However, there has been the research which has found the fact that accountability significantly and positively affects people trust in government (Nurrizkiana et al., 2017). It means that management which is accountable may increase the stakeholder's trust in the institution. Then, it is expected that an accountable management will increase muzakki's trust in zakat board. Since trust has affective and cognitive dimensions, this research predicted that accountability would increase muzakki's affective trust on zakat institution. Based on the above description, the third hypothesis is formulated as follows.

H3: Accountability positively affects affective trust.

\section{The influence of accountability on cognitive trust}

Using the same logic that was applied to the third hypothesis, the relation between accountability and cognitive trust can also be explained based on Attribution theory and Agency theory. The results of some previous research imply that there have been no discussions about the influence of accountability on cognitive trust. The fourth hypothesis predicts that accountability positively affects cognitive trust according to the research conducted by Nurrizkiana et al. (2017) which showed that accountability positively and significantly affected trust. Hence, it can be concluded that accountability positively affects muzakki's cognitive trust in zakat institution. An accountable zakat institution will form muzakki's opinion that the zakat institution is competent and professional in executing its duty. Based on the above description, the fourth hypothesis is formulated as follows.

H4: Accountability positively affects cognitive trust.

\section{The influence of affective and cognitive trust on interest in paying zakat}

It has been explained that trust is an important factor in exchange transaction between business partners (Robbins \& Judge, 2008). Trust is the conviction of one party to the other party that the other party is competent, open, caring, and reliable (Zur et al., 2012). When each of the parties develops trust between them, those parties then will be likely to build good cooperation. In other words, if muzakki's trust in zakat institution increases, muzakki's interest in paying zakat through zakat institution will also increase.

There has been some research testing the influence of trust in the interest in paying zakat through zakat institution. Sidiq (2015) conducted a test on the influence of trust level on the interest in paying zakat to zakat board in Muhammadiyah University of Surakarta. The result showed that trust significantly and positively affected the interest in paying zakat to zakat institution. Moreover, Azimah (2016) investigated the influence of trust on the interest in paying zakat in BAZNAS of Gresik Regency. The result showed that trust variable significantly and positively affected the interest in paying zakat. In addition, Triyawan and Aisyah (2016) also showed that trust significantly and positively affected the interest in paying zakat through BAZNAS of Yogyakarta. Rouf (2011) had conducted a test on the influence of trust, religiosity, and income on people's interest in paying zakat in Semarang branch of "Rumah Zakat", and the result showed that trust was significantly and positively proven to affect people's interest in paying zakat in Semarang branch of "Rumah Zakat".

In spite of the fact that some researchers have successfully found positive relations between trust and interest in paying zakat through zakat institution, there has been no research that investigated the influence of affective and cognitive trusts on the interest in paying zakat through zakat institution. Since trust has affective and cognitive dimensions, the foregoing studies which implied the influence of trust in interest in paying zakat can be used as a basis to formulate the following fifth and sixth hypotheses:

H5: Affective trust positively affects interest in paying zakat through zakat institution.

H6: Cognitive trust positively affects interest in paying zakat through zakat institution. 


\section{Research Model}

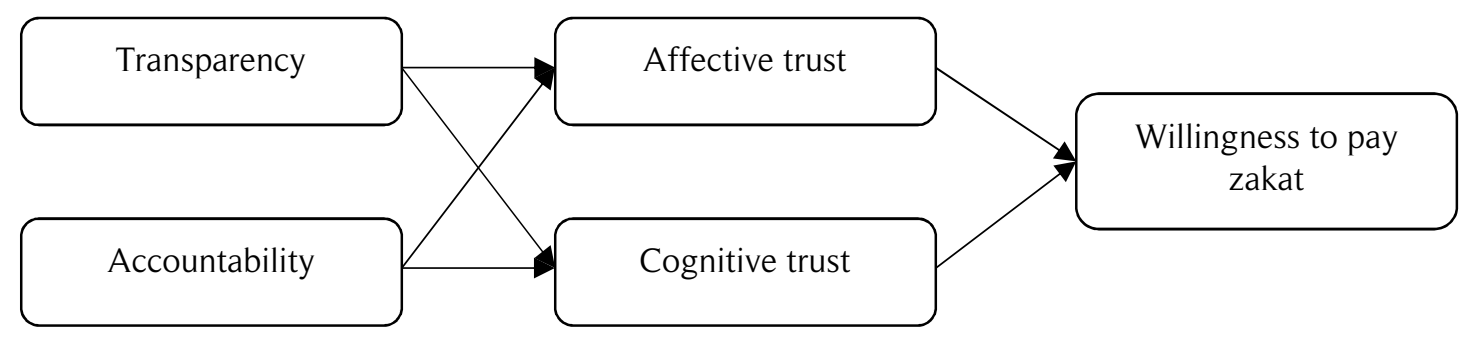

Picture 1: Research Model

\section{Research Method}

\section{Data and Sample Collection Method}

The data collection process was performed by distributing questionnaires both through BAZNAS and by the researchers themselves (the researchers directly met the respondents). The population in this research was a number of muzakkis from BAZNAS Provincial Office of Yogyakarta Special Region and BAZNAS Office of Yogyakarta City. Due to the large number of populations, the research samples taken by the researcher were only 130 muzakkis domiciled in Yogyakarta Special Region. The sampling selection was performed using the purposive method for each office, where 90 muzakkis were from BAZNAS Provincial Office of Yogyakarta Special Region, and 40 muzakkis were from BAZNAS of Yogyakarta City. Of the 130 questionnaires distributed, 100 were returned (70 from BAZNAS Provincial Office; 30 from BAZNAS of Yogyakarta City) which were then used as the data of this research.

\section{Operational Definition and Measurement of the Variable}

This research used 5 variables, including transparency, accountability, affective trust, cognitive trust, and interest in paying zakat through zakat institution. Transparency is a situation in which zakat institution is able to provide the accessible relevant information which can be easily understood by muzakki (KNKG, 2006).

Accountability is defined as an effort or activity to produce an appropriate disclosure. Accountability is performed firstly for Allah SWT. Accountability is also attached with the social role in which muhtasib (accountant) is believed to implement sharia law and that social welfare becomes the main objective of the zakat institution activity (Abu-Tapanjeh, 2009).

The next variables were affective trust and cognitive trust. Cognitive trust is the belief or willingness of muzakki to rely on the competence and reliability of zakat institution, while affective trust is the belief in zakat institution on the basis of a feeling resulting from the attention level of the institution on muzakki. This affective trust is signaled by the sense of being protected when interacting with zakat institution (Johnson \& Grayson, 2005).

The fifth variable was interest in paying zakat through zakat institution. Interest is a situation where muzakki has an attention on zakat institution which is accompanied by a willingness to pay zakat through the zakat institution (Mus'ab, 2011). The measurement of all variables is explained in Table 1. The instrument was measured using four (4) rating scales starting from strongly disagree, disagree, agree, to strongly agree.

Table 1: Measurement of variables

\begin{tabular}{|c|c|c|}
\hline & Indicator & Question Item \\
\hline Transparency & $\begin{array}{l}\text { 1. All information about zakat institution } \\
\text { must be easily accessible by parties who } \\
\text { take an interest in the information. } \\
\text { 2. All information owned by zakat institution } \\
\text { must be disclosed honestly and } \\
\text { completely, and all the matters in the } \\
\text { activity must be conveyed. } \\
\text { 3. Conveyance of the information must also } \\
\text { be performed well and fairly to all parties } \\
\text { who need the information. } \\
\text { Source: Khaerany (2013) }\end{array}$ & $\begin{array}{l}\text { 1. Whether BAZNAS financial report is } \\
\text { published periodically. } \\
\text { 2. Whether financial report and program } \\
\text { disclosure can be freely accessed by the } \\
\text { public. } \\
\text { 3. Whether BAZNAS discloses all zakat } \\
\text { management activities to muzakki. } \\
\text { 4. Whether BAZNAS publishes financial } \\
\text { report to the stakeholder } \\
\text { 5. Whether BAZNAS discloses the whole } \\
\text { financial condition to the stakeholder }\end{array}$ \\
\hline
\end{tabular}




\begin{tabular}{|c|c|c|}
\hline & Indicator & Question Item \\
\hline & & $\begin{array}{l}\text { 6. Whether BAZNAS writes down its policy } \\
\text { and discloses it to the stakeholder } \\
\text { 7. Whether muzakki understand the financial } \\
\text { policy and activities issued/performed by } \\
\text { BAZNAS. }\end{array}$ \\
\hline Accountability & $\begin{array}{l}\text { 1. All activities must consider and prioritize } \\
\text { public welfare as the manifestation of } \\
\text { trusteeship given by Allah SWT to human } \\
\text { as the khalifah. } \\
\text { 2. Organization activity is performed fairly. } \\
\text { 3. Organization activity is not damaging the } \\
\text { surrounding environment. } \\
\text { 4. The management must be accompanied by } \\
\text { a good control in accordance with the } \\
\text { commitment made between trustee and } \\
\text { trustee recipient. } \\
\text { 5. Management is performed based on Islam } \\
\text { sharia determined by Qor'an. } \\
\text { Source: Khaerany (2013) }\end{array}$ & $\begin{array}{l}\text { 1. Whether zakat distribution is performed by } \\
\text { considering mustahik needs. } \\
\text { 2. Whether the programs performed by } \\
\text { BAZNAS can increase mustahik welfare. } \\
\text { 3. Whether every mustahik receives the zakat } \\
\text { fairly. } \\
\text { 4. Whether every muzakki get fair treatment } \\
\text { from zakat institution. } \\
\text { 5. Whether zakat distribution program } \\
\text { performed by BAZNAS is not damaging } \\
\text { environment's stability. } \\
\text { 6. Whether zakat is distributed to the proper } \\
\text { mustahik, or the eight groups deserved to } \\
\text { receive zakat. }\end{array}$ \\
\hline \multirow[t]{2}{*}{$\begin{array}{l}\text { Affective and } \\
\text { Cognitive Trust }\end{array}$} & $\begin{array}{l}\text { 1. Affective trust is a trust to partner on the } \\
\text { basis of feeling resulted by } \\
\text { partner's/company's attention level to the } \\
\text { customers. This affective trust is signaled } \\
\text { by the feeling of being protected during } \\
\text { transaction with company. Affective trust } \\
\text { is related to the perception that partner's } \\
\text { action is intrinsically motivated. } \\
\text { 2. Cognitive trust is customers' trust or } \\
\text { willingness to rely on the competence and } \\
\text { reliability of the service provider. The trust } \\
\text { emerges from the accumulation of } \\
\text { knowledge that enables someone to make } \\
\text { a prediction, with several trust level, } \\
\text { regarding the possibility that partner will } \\
\text { fulfill its duty. }\end{array}$ & $\begin{array}{l}\text { A. AFFECTIVE TRUST } \\
\text { 1. As muzakki, I have the freedom to convey } \\
\text { my ideas and thoughts to BAZNAS. } \\
\text { 2. BAZNAS is willing to help me with the } \\
\text { difficulties related to zakat payment. } \\
\text { 3. Every time I convey my problem regarding } \\
\text { to zakat payment, BAZNAS will properly } \\
\text { give a feedback. } \\
\text { 4. I feel lost if not paying zakat through } \\
\text { BAZNAS. } \\
\text { 5. There is an emotional closeness between } \\
\text { me and BAZNAS. } \\
\text { B. COGNITIVE TRUST } \\
\text { 1. BAZNAS employees work professionally } \\
\text { and in a dedicated manner. } \\
\text { 2. I cannot see the reason to doubt BAZNAS } \\
\text { employee's competence and ability in } \\
\text { performing their job. } \\
\text { 3. I can rely on BAZNAS to manage the zakat } \\
\text { I paid. } \\
\text { 4. I think, BAZNAS can be trusted and } \\
\text { respected by various stakeholders. } \\
\text { 5. The people I know think that BAZNAS can } \\
\text { be trusted. }\end{array}$ \\
\hline & Source: Johnson and Grayson (2005) & $\begin{array}{l}\text { 6. If more people know about BAZNAS, they } \\
\text { will be interested to cooperate with it. }\end{array}$ \\
\hline $\begin{array}{l}\text { Interest in Paying } \\
\text { Zakat through } \\
\text { Zakat Institution }\end{array}$ & $\begin{array}{l}\text { 1. There is the urge in an individual and } \\
\text { muzakki's curiosity. } \\
\text { 2. There is a social motive that evokes the } \\
\text { willingness to do a certain activity. } \\
\text { 3. There is an emotional factor related to } \\
\text { emotion that encourages muzakki to pay } \\
\text { zakat. } \\
\text { Source: Musha'ab (2011) }\end{array}$ & $\begin{array}{l}\text { 1. I am interested in paying zakat through } \\
\text { BAZNAS. } \\
\text { 2. For this year and on, I want to pay zakat } \\
\text { through BAZNAS. } \\
\text { 3. I believe that paying zakat through } \\
\text { BAZNAS is the best choice. }\end{array}$ \\
\hline
\end{tabular}

\section{Results and Discussion}

\section{Respondents Based on Gender}

Respondent of the study regarding the gender is shown in Table 2 . 
Table 2: Respondent based on gender

\begin{tabular}{lll}
\hline Gender & Frequency & Percentage $(\%)$ \\
\hline Male & 62 & 62,0 \\
Female & 38 & 38,0 \\
Total & 100 & $100 \%$ \\
\hline
\end{tabular}

Source: Result of data processing, 2018.

\section{Respondents Based on Age}

Based on the questionnaire, a complete description of the respondents' based on age will be shown in Table 3 .

Table 3: Respondents based on age

\begin{tabular}{lll}
\hline Gender & Frequency & Percentage $(\%)$ \\
\hline$<25$ years old & 15 & 15,0 \\
$26-35$ years old & 19 & 19,0 \\
$36-45$ years old & 24 & 24,0 \\
$46-55$ years old & 35 & 35,0 \\
$>55$ years old & 7 & 7,0 \\
Total & 100 & $100 \%$ \\
\hline
\end{tabular}

Source: Result of data processing, 2018.

\section{Measurement Model}

The measurement model for all constructs (variables) was assessed by examining internal consistency as well as convergent and discriminant validities (Hulland, 1999). Composite reliability scores of constructs exceeded the threshold of 0.70 , indicating internal consistency (Nunnally, 1978). The highest composite reliability was the interest in paying zakat through zakat institution (0.995) and the lowest was transparency (0.888).

The AVE scores for all constructs were much higher than the generally recognized cutoff value of 0.5 , demonstrating convergent validity. The interest in paying zakat has the highest AVE score $(0,984)$ and the lowest was transparency $(0,726)$. In addition, loadings of all items above 0.70 ( the lowest was 0.793 ), providing additional evidence for convergent validity.

Although the measurement model meets the internal consistency and convergent validity, the test of the measurement model shows that discriminant validity is low. This is because some correlations between constructs (variables) are higher than the square roots of the AVE scores. The square root of AVE for transparency, accountability, affective trust, cognitive trust and interest in paying zakat are 0.852, 0.896, 0.952, 0.981 and 0.992 respectively.

\section{Descriptive Analysis}

According to the descriptive analysis, the average value of the respondents' assessments on transparency variable was 3.30 (i.e. BAZNAS is transparent); meanwhile, the average value of the respondents' assessment on accountability variable was 3.45 . In addition, the average value of the respondents' assessment on affective trust variable was 3.25. The fourth variable which was cognitive trust recorded the average value from the respondents' assessment as much as 3.47. Also, the last variable, interest in paying zakat, obtained the average value from the respondents' assessment amounting 3.42. As stated above, the measurement of all variables employed four (4) rating scales ranging from strongly disagree, disagree, agree, and strongly agree. From the descriptive analysis, it could be concluded that all the average scores of all variables were included in the "agree" criteria.

\section{Inner Model (Structural Model)}

Inner model (structural model) was used for hypothesis testing. The coefficient determination of the model $\left(\mathrm{R}^{2}\right)$ will be shown in Table 4.

Table 4: Coefficient determination

\begin{tabular}{lll}
\hline & $\mathrm{R}^{2}$ & Adjusted $\mathrm{R}^{2}$ \\
\hline Cognitive Trust & 0,849 & 0,841 \\
Affective Trust & 0,844 & 0,846 \\
Interest to Pay & & \\
Zakat & 0,974 & 0,973 \\
\hline
\end{tabular}

Source: Result of data processing, 2018. 
According to Table 4, transparency and accountability were able to explain the variability of cognitive trust in the amount of $84.9 \%$, the rest $15.1 \%$ was explained by another variable outside the ones being investigated in this research. Meanwhile, transparency and accountability were able to explain the variability of affective trust in the amount of $84.4 \%$, the rest $15.6 \%$ was explained by another variable outside the ones being investigated in this research. As for the affective and cognitive trust, they were able to explain the variability of interest in paying zakat in the amount of $97.4 \%$, and the rest $2.6 \%$ was explained by another variable outside the ones being investigated in this research.

\section{Hypothesis Testing}

To see whether the hypotheses were supported, the researcher investigated the coefficient, t-statistics, and p-values indicated in Table 5. Using smart PLS 3.0, the values indicated in Table 5 were taken from bootstrapping process. The rules of thumb used in this research was t-statistics larger than 1.96 with significance value or $p$-value more than $5 \%$.

Table 5: Hypothesis testing

\begin{tabular}{llll}
\hline Relation between variables & Coefficient & t Value & p Value \\
\hline Transparency ->Affective trust & 0.106 & 0.951 & 0.342 \\
Transparency -> Cognitive trust & 0.027 & 0.314 & 0.753 \\
Accountability -> Affective trust & 0.853 & 4.280 & 0.000 \\
Accountability -> Cognitive trust & 0.905 & 4.604 & 0.000 \\
Affective trust ->Interest to pay zakat & 0.213 & 2.016 & 0.044 \\
Cognitive trust -> Interest to pay zakat & 0.779 & 4.581 & 0.000 \\
\hline
\end{tabular}

Source: Result of data processing, 2018.

Table 5 shows that the coefficient of transparency and affective trusts relation was very small amounting only 0.106 with $p$ value $>0.05$, hence, it could be concluded that the first hypothesis was not supported. The second hypothesis could not be supported as well because the coefficient of transparency and cognitive trusts relation was 0.027 with $p$ value $>0.05$. Meanwhile, the coefficient of accountability and affective trusts relation was 0.853 with $\mathrm{p}$ value $<0.05$, so it could be assumed that the third hypothesis was validated. Similar to the third hypothesis, the fourth hypothesis could also be accepted because the coefficient of accountability and cognitive trusts relation was 0.905 with $p$ value $<0.05$. The fifth and sixth hypotheses were also confirmed with each of $p$ values of both affective and cognitive trusts was $<0.05$ and coefficients were 0.213 and 0.779 respectively.

\section{Discussion}

\section{The influence of transparency on affective trust}

This research predicted that the transparency of zakat institution would positively affect muzakki's affective trust on zakat institution. However, the result showed that transparency of zakat institution did not affect muzakki's affective trust. The amount of foregoing research discussing the influence of transparency on trust in zakat institution was not really large, one of which was by Nasim and Romdhon (2014). Different from this research, Nasim and Romdhon (2014) found the evidence that transparency positively and significantly affected muzakki's trust in zakat institution. Conducting research in public sector, Nurrizkiana et al. (2017) showed the evidence that transparency affected people's trust in government, and the result of this research supported the finding generated by Nasim and Romdhon (2014). In his conceptual study concerning tax, Kiow et al. (2017) stated that transparency had a positive effect on people's ethical perception towards government which stated that the perception would eventually increase people's tax compliance. Transparent environment will increase taxpayer's trust in public organization. Taxpayer takes an interest in the transparency of public sector management because the lack of transparency can cause corruption and decrease public sector's efficiency.

Other researchers argue that transparency is one of the "best practice 'dimensions of zakat management. As a part of compliance with the responsibility to the public, zakat institution ought to submit zakat management report to the related stakeholders (such as public, government, and parliament). They have to ensure that there is a standardization of transparent and accountable zakat management. The report of zakat institution must include at least annual financial report audited by an authorized auditor, zakat collection and distribution report, and also sharia audit report (Zaenal et al. 2016).

Even though it was conceptually believed that transparency will bring positive effect, the result of this research found that transparency performed by BAZNAS was not effective to increase the affective trust of 
muzakkis. The result of this study does not support Attribution and Agency theories. The explanation why transparency did not affect affective trust is that the muzakki's internal factor was in form of individual character. Affective trust consists of what is felt towards an object, or, in other words, things that are related to emotion. The factors from the inside of the muzakki candidates also affect their belief in zakat administrating institution (BAZNAS). The existence of different characters in each muzakki or the circulating issue of the institution affects the muzakki's mindset and trust. Therefore, the difference between the result of this research and those of the previous research was likely due to the different objects and respondents. Nasim and Romdhon (2014) conducted a research on zakat institution in Bandung, while Nurrizkiana et al. (2017) conducted a research in public sector, while this research was conducted in BAZNAS of Yogyakarta. Syawaluddin et al. (2016) declared that the contractual relationship between zakat institution and public (muzakki) was more likely to be affected by cultural norms and values rather than control mechanism used by a company. Rationality raised in an organization is a form of agent mental construction based on local and specific social experiences.

The result of this research will support zakat administrating institution especially BAZNAS to increase the transparency by providing information (which is related to zakat resource management) for those who need it in details. The openness of zakat administrating institution (BAZNAS) is a factor that may affect muzakki's emotion so that the muzakki will give more trust in the institution. There are various ways to create a situation where transparency will be implemented accordingly in an institution involving various parties, those are from the institution (internal) and from muzakki (external). The internal party, including zakat manager, should always monitor the quality of information transparency, and the external party should always encourage zakat institution administrator to consider transparency aspect. The balance between the two factors will give a better control.

\section{The influence of transparency on cognitive trust}

The result of this study also showed that zakat institution transparency did not affect muzakki's cognitive trust. It is not in line with the findings of the research conducted by Nasim and Romdhon (2014) and by Nurrizkiana et al. (2017) because those researchers found that transparency positively and significantly affected public/muzakki's trust. The result showing that the transparency of zakat institution, especially BAZNAS, was less effective to increase muzakki's cognitive trust. Furthermore, the result also showed that Agency theory and Attribution theory could not obtain the empirical supports.

Since the discussion of the first and second hypothesis generates a consistent result, (that transparency does not affect affective and cognitive trust), it is reliable to assume that zakat institution, specifically BAZNAS, must review its financial report transparency, especially the transparency aspect which does not only consider the amount of information but also the convenience of the stakeholders to access the information. Hence, it can be concluded that the difference between the result of this research and those of the previous research occurred because the transparency performed by BAZNAS was not yet effective to increase muzakki's cognitive trust. Different location, object, and respondent brought the failure for this research to support two hypothesis and the results of the previous research.

\section{The influence of accountability on affective trust}

The analysis of third hypothesis which states that accountability of zakat institution positively and significantly affects muzakki's affective trust was in line with the result of research conducted by Nurrizkiana et al. (2017). Accountability is a form of zakat institution responsibility for all of its performed activities which should be published in a form of a report. Affective aspect is a component affecting someone's emotion. To increase muzakki's trust, zakat institution should have an accountable attitude. As a manifestation of responsibility, BAZNAS should perform its duty by doing the accountable management in a good way.

Saad et al. (2014) in their conceptual study also emphasized the importance of accountability in zakat fund management. Different from the western understanding on accountability, Islamic accountability framework proposed and analyzed here provides a broad and integrated understanding on zakat fund management. In Islamic perspective, the concept of zakat institution accountability is mainly intended to Allah, followed by the responsibility to government, zakat payer, and zakat receiver. Accountability in zakat fund management is inseparable from Islamic teaching.

Based on the theory used in this research, namely Attribution theory, zakat institution accountability affects muzakki's affective trust due to the existence of behavior caused by the internal factors (which is believed to be under control of the individual oneself). It means that an individual (or muzakki in this research) believes in their own behavior. It implies that BAZNAS sense of responsibility has successfully granted positive impacts to muzakkis 
so that the muzakkis will trust and feel protected when entrusting their fund for zakat to BAZNAS. Therefore, BAZNAS will be considered to be able to grow the muzakkis' trust and affect their positive emotions.

The researcher has not yet successfully found the research on zakat institution that relates the influence of accountability to trusts, especially affective and cognitive trusts. The research conducted by Nurrizkiana et al. (2017), to which this research referred, focused on public sector. Although the very part of this study supports the result of previous research, the future research still needs to investigate the role of accountability to strengthen muzakki's trust.

\section{The influence of accountability on cognitive trust}

In accordance with the hypothesis, the accountability of zakat institution positively and significantly affects cognitive trust. This finding was in line with that of the research conducted by Nurrizkiana et al. (2017) which insisted that accountability positively and significantly affected public trust. Accountability means the responsibility of zakat institution to be fair in performing all of its activities. Cognitive aspect is an opinion or experience owned by an individual. Trust will develop based on personal experience or other people's experience.

According to Attribution theory, accountability of zakat institution affects muzakki's cognitive trust due to the behavior caused by internal factors (the behavior is believed to be under control of the individual oneself), and it means that the individual (muzakki) believes in his/her own behavior. In this case, BAZNAS as a zakat managing institution is expected to perform its responsibility by providing a considerably good liability so that muzakki has no doubt and believes in the institution. Cognitive trust may only be constructed in a long term. BAZNAS will be considered to be successful when it could consistently endure its responsibility in an adequately long term.

The analysis result of the third and fourth hypotheses showed that accountability positively and significantly affected the affective and cognitive trust, indicating that BAZNAS accountability system was already effective in increasing two dimensions of trusts. The finding also supports Agency theory and Attribution theory.

Htay and Salman (2013) explained in their paper that Agency theory from Islamic perspective considered that people, whether they were recent muzakkis or future muzakkis, entrusted their zakat to zakat institution so that it would be delivered to those who deserved to receive it, and the agent/zakat administrator considered that the trust to manage the zakat was a trusteeship. Therefore, zakat institutions must do their best to fulfill their contractual duty and responsibility through a set of information and reporting system that will be used as the liability tool.

\section{The influence of affective trust on interest in paying zakat}

The analysis result of the fifth hypothesis indicated that affective trust positively and significantly affected interest to pay zakat. This statement is in line with the research conducted by Rouf (2011), Sidiq (2015), Azimah (2016), Yunus (2016), as well as Triyawan and Aisyah (2016). The foregoing studies found that trust affected interest in paying zakat through zakat institution. Similarly, this research found that affective trust affected interest in paying zakat. It indicates that muzakki's trust in zakat administrating institution (BAZNAS) is considered good. Affective trust consists of the things we feel about an object, or, in other words, things that are related to emotion. Positive emotion can encourage someone to pay zakat with sincere feeling without the element of compulsion. One of the background aspects of muzakki's trust in a zakat institution is the knowledge about the obligation to pay zakat and detailed explanation from the institution. This statement is also in line with the findings of Azman and Bidin (2015) in an empirical study conducted in Malaysia which analyzed the influence of credibility concept that was similar to the concept of trust, and they proved that the credibility of zakat institution significantly affected the compliance in paying income zakat.

Zakat administrating institution must be spared from negative issues, so it can be deemed as a trusted institution by the society. Good performance in giving explanation as well as giving an awareness regarding the importance of paying zakat and transparency in zakat distribution are the basic assets to create safe feeling and trust for muzakki (Satrio \& Siswantoro, 2016). The feeling of safe and trust generate a good opinion and positive emotion of muzakki. As a result, BAZNAS indirectly increases the interests of other muzakki candidates. Based on Attribution theory, the behavior exists due to the internal factors. The muzakki believes that the existence of trust affects the interest in paying zakat. Interest or awareness to pay zakat will affect the continuity of zakat organizing institution in the future. 


\section{The influence of cognitive trust on the interest in paying zakat}

The sixth hypothesis test indicated that cognitive trust positively and significantly affected interest in paying zakat, and this statement is in line with the research conducted by Rouf (2011), Sidiq (2015), Azimah (2016), Yunus (2016), as well as Triyawan and Aisyah (2016). The foregoing studies have found that trust affects interest in paying zakat, and this research found that cognitive trust positively affected interest in paying zakat through zakat institution.

Creating safe and comfortable feeling in the cooperation with other parties will give positive impact for zakat administrating institution (BAZNAS). To perform an evaluation at the end of each activity is a good step to fix the mistake that has been done, thus, in the future BAZNAS will be able to give a satisfying service to the muzakkis. Another important thing is creating a good perception of zakat administrating institution (BAZNAS) in the provision of optimal service and performance for the muzakki. The creation of good perception and image will affect the interest of society in paying zakat (Nur'aini \& Ridla, 2015). It is expected that all employees of zakat administrating institution (BAZNAS) can maintain the good name and performance of the institution to remain well recognized by people.

\section{Conclusion}

As explained in the discussion, this research investigated muzakki's interest/willingness to pay zakat through zakat institution, and the subject of this research was BAZNAS in Yogyakarta. Four out of six hypotheses tested in the research model were supported. In accordance with the hypothesis, accountability positively affects affective and cognitive trusts. The fact that affective and cognitive trusts positively affect muzakki's interest in paying zakat through zakat institution gives the empirical support to Attribution theory and Agency theory.

However, this research failed to support the hypothesis stating that transparency positively affects affective and cognitive trusts which implies that transparency has not yet been effective to increase the two dimensions of trust concept. It also indicates that zakat institution, especially BAZNAS, needs to perform various efforts to increase the effectiveness of accounting information transparency.

The result of this research has suggested that accountability positively affects affective and cognitive trusts which indicates that the accountability system of zakat institution, especially BAZNAS, is already effective to increase the two dimensions of trust. Therefore, accountability system must always be monitored, and the quality of accountability system should be continuously maintained. Besides, the research has also shown that affective and cognitive trusts positively affect muzakki's interest in paying zakat through zakat institution. It argues that zakat institution, especially BAZNAS, must consider and maintain affective and cognitive trusts of the muzakki in BAZNAS. Theoretically, the findings of this research support the literature discussing the importance of trust variables, both affective and cognitive.

All in all, this research has successfully expanded the results of foregoing studies by finding the evidence of the influence of accountability on affective and cognitive trusts as well the influence of affective and cognitive trusts on muzakkis' interest in paying zakat through zakat institution. This research can be used as a suggestion for the policy makers to perform various efforts to increase people's trust in zakat institution so that people's interest in paying zakat through zakat institution/zakat administrating organization will increase.

Due to the large number of question items, this research could only provide respondent demographic data in terms of age and gender which could be considered as the limitation of this research. There has been much previous research investigating the influence of trust on interest in paying zakat; however, only a little amount of research investigated trust determinant towards zakat institution, especially transparency and accountability. Hence, this fact is expected to open the opportunity for the related future research.

\section{References}

Abu-Tapanjeh, A. M. (2009). Corporate governance from the islamic perspective: a comparative analysis with OECD principles. Critical Perspectives on Accounting, 20(5), 556-567. https://doi.org/10.1016/j.cpa.2007.12.004

Ali, K. M. (2014). Integrating zakah, awqaf and Islamic microfinance for poverty alleviation: Three models of Islamic micro finance. IRTI Working Paper Series for Islamic Research and Training Institute.

Azimah, N. H. (2016). Pengaruh religiusitas, gaji dan kepecayaan terhadap minat muzakki membayar zakat di badan amil zakat nasional (BAZNAS) kabupaten gresik. UIN Sunan Ampel Surabaya.

Azman, F. M. N., \& Bidin, Z. (2015). Factors influencing zakat compliance behavior on saving. International Journal of Business and Social Science, 5(1), 118-128. 
BAZNAS. (2018). Statistik zakat nasional 2017. Retrieved from https://pid.baznas.go.id/wpcontent/uploads/2019/02/STATISTIK-ZAKAT-NASIONAL-2017.pdf

Canggih, C., Fikriyah, K., \& Yasin, A. (2017). Inklusi pembayaran zakat di indonesia. Jurnal Ekonomi Dan Bisnis Islam, 3(1), 1-11.

Eisenhardt, K. M. (1989). Agency Theory: An assessment and review. The Academy of Management Review, 14(1), $57-74$.

Htay, S. N. N., \& Syed, A. S. (2013). Agency theory, stewardship theory and stakeholder theory: an Islamic perspective. International Journal of Physical and Social Sciences, 3(9), 319-332. Retrieved from http://irep.iium.edu.my/32027/

Hulland, J. (1999). Use of partial least squares (PLS) in strategic management research: A review of four recent studies. Strategic Management Journal, 20(2), 195-204.

Jensen, M. C., \& Meckling, W. H. (1976). Theory of the firm: Management behavior, agency costs and ownership structure. Journal of Financial Economics, 3(1976), 305-360. https://doi.org/10.1016/0304405X(76)90026-X

Johnson, D., \& Grayson, K. (2005). Cognitive and affective trust in service relationships. Journal of Business Research, 58(4), 500-507. https://doi.org/10.1016/S0148-2963(03)00140-1

Khaerany, R. (2013). Akuntabilitas dan transparansi lembaga pengelola zakat terhadap kualitas lembaga amil zakat (pandangan muzakki dan amil zakat pada dompet dhuafa Sulsel) (Hasanuddin University). Retrieved from http://repository.unhas.ac.id/handle/123456789/4804

Kiow, T. S., Salleh, M. F. M., \& Kassim, A. A. B. M. (2017). The determinants of individual taxpayers' tax compliance behaviour in Peninsular Malaysia. International Business and Accounting Research Journal, 1(1), 26-43. https://doi.org/10.15294/ibarj.v1i1.4

Komite Nasional Kebijakan Governace (KNKG). (2006). Pedoman Umum Good Corporate Governance. Jakarta: KNKG.

McAllister, D. J. (1995). Affect and cognition based trust as foundations for interpersonal cooperation in organizations. Academy of Management Journal, 38(1), 24-59. https://doi.org/10.2307/256727

Musha'ab, A. (2011). Pengaruh religiusitas tingkat penghasilan, dan layanan terhadap minat muzakki untuk membayar zakat maal di lazis $N U$ (Universitas Islam Negeri Sunan Kalijaga). Retrieved from http://digilib.uin-suka.ac.id/9837/1/BAB I\%2C BAB V\%2C DAFTAR PUSTAKA.pdf

Nasim, A., \& Romdhon, M. R. S. (2014). Pengaruh transparansi laporan keuangan, pengelolaan zakat, dan sikap pengelola terhadap tingkat kepercayaan muzakki. Jurnal Riset Akuntansi Dan Keuangan, 2(3), 550-561. https://doi.org/http://dx.doi.org/10.17509/jrak.v2i3.6603

Nunnally, J. (1978). Psychometric theory. New York: McGraw-Hill.

Nur'aini, H., \& Ridla, M. R. (2015). Pengaruh Kualitas Pelayanan, Citra Lembaga dan Religiusitas Terhadap Minat Muzakki Untuk Menyalurkan Zakat Profesi (Studi di Pos Keadilan Peduli Ummat Yogyakarta). Jurnal Manajemen Dakwah, 1(2), 207-228. https://doi.org/https://doi.org/10.14421/jmd.2015.\%25x

Nurrizkiana, B., Handayani, L., \& Widiastuty, E. (2017). Determinan transparansi dan akuntabilitas pengelolaan keuangan daerah dan implikasinya terhadap kepercayaan public stakeholders. Jurnal Akuntansi Dan Investasi, 18(1), 28-47. https://doi.org/10.18196/jai.18159

Rahman, A. R. A. (1998). Issues in corporate accountability and governance: an islamic perspective. The American Journal of Islamic Social Sciences, 15(1), 55-69.

Robbins, S. P., \& Judge, T. A. (2013). Organizational Behaviour Individuals (15th ed.). Boston: Pearson.

Ross, S. A. (1973). The economic theory of agency: the principal' s problem. The American Economic Review, 63(2), 134-139.

Rouf, M. A. (2011). Analisis faktor-faktor yang mempengaruhi minat masyarakat membayar zakat di rumah zakat cabang semarang. IAIN Walisongo. 
Saad, R. A. J., Aziz, N. M. A., \& Sawandi, N. (2014). Islamic Accountability Framework in the Zakat Funds Management. Procedia-Social and Behavioral Sciences, 164, 508-515. https://doi.org/10.1016/j.sbspro.2014.11.139

Satrio, E., \& Siswantoro, D. (2016). Analisis faktor pendapatan, kepercayaan dan religiusitas dalam mempengaruhi minat muzakki untuk membayar zakat penghasilan melalui lembaga zakat. Simposium Nasional Akuntansi XIX, 1-22. Lampung: Ikatan Akuntan Indonesia Kompartemen Akuntan Pendidik (IAI KAPd).

Sharif, A. M., Jusoh, W. N. H. W., Mansor, N., \& Jusoff, K. (2011). A robust zakah system : Towards a progressive socio-economic development in Malaysia. MIddle-East Journal of Scientific Reseaerch, 7(4), 550-554.

Sidiq, H. A. (2015). Pengaruh pengetahuan zakat, tingkat pendapatan, religiusitas dan kepercayaan kepada organisasi pengelola zakat terhadap minat membayar zakat pada lembaga amil zakat. Universitas Muhammadiyah Surakarta.

Syawaluddin, S., Ananda, C. F., Manzilati, A., \& Hoetoro, A. (2016). Principal agent relationship on zakah institution in Indonesia. International Journal of Scientific \& Technology Research, 5(6), 204-210.

Triyawan, A., \& Aisyah, S. (2016). Analisis faktor-aktor yang mempengaruhi muzakki membayar zakat di BAZNAS Yogyakarta. Jurnal Islamic Economics Journal, 2(1), 53-69.

Undang-Undang Republik Indonesia Nomor 23 Tahun 2011 Tentang Pengelolaan Zakat.

Yunus, M. (2016). Analisis pengaruh kepercayaan, religiusitas dan kontribusi terhadap minat pedagang mengeluarkan zakat di baitul mal (studi kasus pada pedagang pasar los lhokseumawe). UIN Sumatera Utara.

Zaenal, M. H., Choirin, M., Tsabita, K., Astuti, A. D., \& Sadariyah, A. S. (2017). Principles of amil zakat and best practice recommendations for zakat institutions. In PUSKAS Working Paper Series (No. PWPS\# 2016-02).

Zur, A., Leckie, C., \& Webster, C. M. (2012). Cognitive and affective trust between Australian exporters and their overseas buyers. Australasian Marketing Journal, 20(1), 73-79. https://doi.org/10.1016/j.ausmj.2011.08.001 